\title{
A Constitution for Peace: Federalism and Consociationalism in Bosnia and Herzegovina
}

\author{
Una constitución para la paz: federalismo y consociacitivismo \\ en Bosnia y Herzegovina
}

Francisco Ignacio Aras (D) Pontificia Universidad Católica Argentina, Argentina | arasfrancisco@gmail.com
Recibido: $\quad 15 / 10 / 2020$
Aceptado: 9/12/2020

Abstract The present paper draws on the Constitution of Bosnia and Herzegovina, resulted from the Dayton Peace Agreement, in order to explain how the elements of federalism and consociationalism can become important tools in the field of transitional justice. By combining federalism and consociationalism, it will be demonstrated how shared-rule and self-rule can be useful in addressing the demands of territorially concentrated ethnic groups for more autonomy and self-government, while at the same time preserving the territorial integrity of the state. It also explains the role of post-conflict constitutional design processes on their ability to reconcile groups, to address intolerable grievances and to prevent further polarization by providing a common vision of the future of a state.

Key words Bosnia and Herzegovina, transitional justice, federalism, consociationalism

Resumen El presente artículo analiza la Constitución de Bosnia y Herzegovina, producto del Acuerdo de Paz de Dayton, con el objeto de explicar cómo los elementos del federalismo y el consociaciativismo pueden convertirse en herramientas fundamentales en el ámbito de la justicia transicional. Al combinar el federalismo y el consociacitivismo, se tratará de mostrar cómo el gobierno compartido y el autogobierno pueden ser útiles para abordar las demandas de más autonomía y autogobierno por parte de los grupos étnicos concentrados territorialmente, al tiempo que preservan la integridad territorial del estado. También explica el rol que ocupan los procesos de diseño constitucional posconflicto para reconciliar diferentes grupos, abordar agravios intolerables y prevenir una mayor polarización al proporcionar una visión común de futuro para un estado.

Palabras clave Bosnia y Herzegovina, justicia transicional, federalismo, consociativismo

Cómo citar este artículo: Aras, F. I. (2020). A Constitution for Peace: Federalism and Consociationalism in Bosnia and Herzegovina. Revista Electrónica de Derecho Internacional Contemporáneo, 3 (3), 127 - 134. https://doi.org/10.24215/2618303Xe008 


\section{Introduction}

In societies scarred by ethnic animosity, one goal of transitional justice is to help reshape identities. In particular, the aim is to weaken aspects of identities that were the source of violence and conflict and replace those with a strengthened sense of shared identity related to common membership in the national political community. This is often described as the "nation-building" dimension of transitional justice.

Minority nationalist movements are characterized precisely by their claims to peoplehood or nationhood, and the adoption of multination federalism reflects an acknowledgement of the need to accommodate this nationalist identity. Territorial autonomy both acknowledges this sense of minority nationhood and provides the institutional means to reproduce it (for example, by enhancing regional control over education, public symbols, public media) (Kymlicka, 2009).

In this sense, federalism has become an important tool of conflict-resolution in the past two decades. In countries that face violence between different territorially concentrated groups, federalism has been used to ensure autonomy for the different groups on one side and their inclusion through power-sharing mechanisms in central government (consociationalism), on the other (Keil, 2012, p. 205). Examples include Bosnia, Nigeria, Iraq and Nepal.

This article, by studying the case of Bosnia and Herzegovina, which became federal as a result of the Dayton Peace Agreement in 1995, argues that federalism and consociationalism might be successful in addressing some needs of different opposing groups. Both are characterized, though in varying degrees, by inclusiveness and contestation and have provided working constitutional models for divided plural societies (Boulle, 1981, p. 237). Because of this, the paper will also draw the importance of constitution making in post-conflict settings.

By combining federalism and consociationalism, it will be demonstrated how shared-rule and self-rule can be useful in addressing the demands of territorially concentrated ethnic groups for more autonomy and selfgovernment, while at the same time preserving the territorial integrity of the state.

\section{Background}

The Republic of Bosnia and Herzegovina, having been one of the six republics of the former Socialist Federal Republic of Yugoslavia, was a Yugoslavia "in miniature" with three peoples: the Muslims, Serbs, and Croats -none of them in an absolute majority position- and 15 national minorities living intermingled on the entire territory until 1991. Bosnia and Herzegovina was seen, therefore, by many both in the West and the East as a model of a multiethnic society with peaceful interethnic co-existence.

This changed with the proclamation of an independent Republika Srpska on the territory of Bosnia in the process of the dissolution of communist Yugoslavia in the beginning of 1992. During the war, from 1992 to 1995, massive ethnic cleansing and the creation of contiguous, ethnically homogenous territories went hand in hand.

In April 1994, the Federation of Bosnia and Herzegovina was also created on the territory held by the army of the Republic of Bosnia and Herzegovina to stop the war between Muslims and Croats which had broken out in 1993 to adjust the military situation on the ground with newly drawn borderlines on maps after the "cantonization" of Bosnia had been proposed by international mediators. Unlike the Republika Srpska, which was established and still is a central state, the Federation became territorially subdivided into ten cantons: five with a majority Muslim population, three with a majority Croat population and two so-called "mixed" cantons (Marko, 2005). 


\section{The road to the Constitution of Bosnia and Herzegovina}

The road to a Constitution of Bosnia and Herzegovina began when the United States, after building some consensus (including a cease-fire), moved to proximity talks to clear the ground for a peace conference at an air force base in Dayton, Ohio. The peace conference was held between November 1 and November 21, 1995. The United Nations and the European Union were major participants. The conference in Dayton allowed the United States to control public participation and the agenda and it appointed the leader of Serbia as the negotiator for the Bosnian Serbs and the leader of the Croatian government for the Bosnian Croats. The consequence of having only political groups in Dayton, with their investment in ethnicity, meant that the state was structured on the basis of ethnicity (Brandt, Cottrell, Ghai and Regan, 2011).

Negotiations were "successful", resulting in the General Framework for Peace in Bosnia and Herzegovina (also known as the Dayton Accords). It consisted of eleven appendices addressing a number of issues, some interconnected (including human rights, peacekeeping, return of refugees, and elections). Appendix 4 contained the Constitution, which is composed by twelve articles and two annexes (Constitution of Bosnia and Herzegovina, 2009).

The Constitution came into effect upon the signing of the agreement by the Republic of Croatia, the Federal Republic of Yugoslavia (basically Serbia), and the Republic of Bosnia and Herzegovina (then dominated by Muslims). No further approval was necessary, although it was taken to the assemblies of the two federal entities, the Federation of Bosnia and Herzegovina and Republika Srpska, for endorsement.

The process was rushed and there was no input from the people of Bosnia; their leaders were completely sidelined. This procedure was more appropriate to war-ending than to constitution-making: it was neither participatory nor representative, and left no time for reasoned deliberation. However, the results are probably more democratic and durable than Bosnians could have produced themselves by the end of the war (Brandt, Cottrell, Ghai and Regan, 2011).

\section{Constitution-making in Transitional Justice}

Fundamentally, a constitution is the basis for the organization of the state. The state is the mechanism through which a society provides for the exercise of political, administrative, and judicial powers so as to ensure law and order, the protection of the rights of the people, and the promotion and regulation of the economy. As the notion of the sovereignty of people has superseded other beliefs about the source of ultimate authority, the constitution has come to be regarded as a contract among people on how they would like to be governed (Brandt, Cottrell, Ghai and Regan, 2011, p. 15).

The design of a constitution and constitution-making process are an integral part of the political and governance transition in peace-building. The benefits of constitutions designed for deeply divided societies hinge on their ability to reconcile groups, to address intolerable grievances and to prevent further polarization. Similarly, it has been argued that the constitution should protect ethnic or religious minorities from oppression by majorities that are subject to permanent passions and prejudice (Elster, 1995, p. 383).

Constitution-making after conflict is an opportunity to create a common vision of the future of a state and a roadmap on how to get there. The constitution can be partly a peace agreement and partly a framework setting up the rules by which the new democracy will operate (Samuels, 2006a, p. 664).

When considering how to provide a constitutional framework for a pluralist state, constitution-makers first turn to the system of government and the structure of the state. In many cases, constitution-making takes place before the actual conflict is settled, and the constitution is then treated as part of the process of conflict 
resolution. In such cases, a power-sharing model is often the only option that will bring the parties to the table and stop the violence (Samuels, 2006b, p. 8).

Current discussions about these choices in ethnically divided societies are framed by a debate between scholars Arend Lijphart and Donald Horowitz. Lijphart argues that majority rule in divided plural societies results in majority dictatorship. This means that no system that depends on a majority form of government is appropriate. Instead, what he refers to as "consociational democracy", which strives to share, divide and distribute power, to draw many groups into decision-making and to emphasize consensus, is the way to go (Lijphart, 1977, in Murray, 2018, p. 3). Horowitz is unpersuaded, particularly because he sees no incentives for groups to cooperate in decision-making in the way that Lijphart envisages. Rather, Horowitz rejects the idea of "ethnic guarantees" and proposes hardware (mainly through the design of the electoral system) that provides incentives for groups to build alliances with each other (Horowitz, 1985).

This paper will address how consociational democracy elements were inserted into the Constitution of Bosnia and Herzegovina, but first it will consider the federal structure that was given to the newly born State.

\section{Federalism}

About 40 percent of world's population live in countries that can be considered as, or claim to be, federal. Federal systems have demonstrated a high level of stability; almost no federation has failed within the European Union or among post-WWII industrial democracies (Loizides, Kovras and Ireton, 2011).

This does not imply that federalism lacks problems, as suggested by several cases of collapse in the former Soviet bloc or in developing countries, not to mention Belgium, a situation which is problematic but relatively stable. Societies that have experienced a collapse in power-sharing agreements tend to hesitate before readopting federal or consociational arrangements. But as we argue here, federalism and power-sharing are often the only possible choices for deeply divided societies. In general, peace processes require difficult tradeoffs between undesirable but unequal alternatives. Federalism and power-sharing might appear problematic, but partition and de facto stalemates are even more so (Loizides, Kovras and Ireton, 2011, p. 2).

First, we must define federalism. K.C. Wheare provided this influential definition of the "federal principle": for a state to be federal, "the general and regional governments must be coordinate and independent in their respective spheres". The constitutional implications of this federal principle included a written constitution expressly conferring powers on the central and regional governments, a system of direct elections for both levels of government, the power of each level of government to act (or not act) independently of the other, and the existence of an independent high court to serve as the "umpire" of federalism (See Choudhry, 2014, p. 165).

Federalism promotes not public accountability or state efficiency but rather peace and territorial integrity (Choudhry, 2014, p. 164). It provides space for regional or cultural differences under a unified national identity and common set of national interests (Williams, Sommadossi y Mujais, 2017). Federalism allows groups that have a history of self-government or a distinct culture or economy to preserve some measure of autonomy. By definition, it offers the benefits of unity without the costs of imposing uniformity on a diverse population (Choudhry, 2014, p. 169).

The core design feature of post-conflict federalism is the drawing of internal borders to ensure that a national minority constitutes a majority in a region. The allocation of jurisdiction between different levels of government ensures that the national minority is not outvoted by the majority and has sufficient powers to protect itself from economic and political disadvantage.

Post-conflict federalism acknowledges that the state contains more than one constituent nation and structures its institutions in such a way as to recognize and empower each of them. Post-conflict federalism halts the 
clamor for secession without dismembering the state, because it satisfies the demand for self-determination with powers of self-government that fall short of independent statehood (Choudhry, 2014, p. 177).

\section{Federalism in the Bosnia and Herzegovina Constitution}

The Dayton Agreement spelled out the new Constitution of Bosnia and Herzegovina, which provided that the two entities, Republika Srpska and the Federation of Bosnia and Herzegovina, are to be regarded as members of a federal state, the Republic of Bosnia and Herzegovina.

In the Bosnian constitution, the basic principles of the federally structured state are present. There is supremacy of the state over the entities, but the entities have a high level of autonomy and participate in the realization of the state competences (Meskic y Pivic, 2011, p. 606).

In this case, federalism is a way of dealing with the nationality matters in multi-ethnic states, a way for the ethnic communities to achieve their interests, their autonomy and to participate in the political life. The internal territorial-political borders determined by the Constitution match the so-called 'ethnic borders' that are the result of the war more than the social circumstances developed through social interaction (Meskic y Pivic, 2011: 606). Furthermore, the three Bosnian constituent peoples -Bosniaks, Serbs and Croats-play a key role in the political institutions at all levels. This is why Bosnia and Herzegovina can be qualified as a multinational federation. The federal system aims at ensuring a fair division and share of powers among the three constituent peoples and the provision of autonomy for these nations in their territorial units (Keil, 2012, p. 207).

\section{Consociationalism}

Traditionally, the focus of political thought has been on how to attain stability in a culturally homogeneous society. The conventional wisdom in political thinking has been, for centuries, the belief that people of different cultures cannot live together peacefully in the same state. This thinking is based upon the assumption that their traditions, languages and laws create differences that are so great as to make these peoples incompatible with one another (Kettley, 2001).

Nevertheless, incentives in the form of power-sharing structures and electoral rules have long been used to shape democracy in order to address division and to encourage moderation. These structures and rules generally take the form of variations on the consociational power-sharing model. Consociational power-sharing involves power-sharing between cooperative but autonomous groups (Samuels, 2006a, p. 673). Essentially, it refers to a political system that is characterized by close elite co-operation between the leaders of the various segments in a divided plural society. What is understood by plural society is one which is divided into two or more communities which are distinct in many respects -culture, race, class, religion, language- and in which political divisions follow these lines of social differentiation. The destructive conflict inherent in such a society is avoided when rival elites realize that more can be gained through co-operation and negotiation at the leadership level and in accommodating, formally or informally, existing sub-cultural differences (Boule, 1981, p. 241).

Lijphart defines consociationalism in terms of four characteristics: the participation by all significant political leaders in a grand coalition, the availability of a mutual veto for all segments represented in the grand coalition, proportionality as the basis of representation in decision-making bodies and as a method of allocating resources and making public appointments, and autonomy for each sub-cultural segment on all matters within the segment's exclusive concern (Lijphart, 1977). 
In all of the cases, where a power-sharing agreement was successfully implemented, it indeed provided an alternative to violent conflict (Lebanon, Northern Ireland, Bosnia and Herzegovina, and South Africa). However, implementation has been a key difficulty. Such agreements generally represent none of the parties' preferred outcomes (Samuels, 2006a, p. 674). Moreover, there is a large trust deficit. In relation to Bosnia and Herzegovina, there is a "deep sense of injury, betrayal and distrust that continues to dominate mutual perceptions and relations between the Bosnian communities in the post-war phase" (Samuels, 2006a).

\section{Consociation in the Bosnia and Herzegovina Constitution}

Pursuant to the Constitution of Bosnia and Herzegovina, the state and the entities share a set of central state institutions in order to guarantee a state-level decision-making process. These are: the three-member Presidency and the Council of Ministers of Bosnia and Herzegovina as the executive authority, the bicameral Parliamentary Assembly as the legislative authority, and the Constitutional Court, as the judicial authority (Trlin, 2017, p. 82).

Each of these bodies, just like all other state institutions, is designed in strict accordance with the principles of consociational power-sharing and the tangible resources of strict ethnic lines providing proportional representation of the "constituent peoples" at all levels and positions. In addition, representatives of the "constituent peoples" have the ability to veto a vital national interest that allows them to block the proposals of laws or policies that they consider harmful to their people.

This set of institutional checks and balances, grounded in the theory of consociation, was created in order to "guarantee the political representation of each ethnic group at the institutional level, in order to protect the right of groups to self-government, and to promote inter-ethnic accommodation and compromise". The structure established by the General Framework Agreement covers all four classical consociation criteria: a grand coalition through the participation of representatives of all major groups in the political decision-making; the autonomy of segments by giving the three ethnic groups the right to perform certain duties determined by the constitution; proportionality through equal representation of ethnic groups; and the veto power enabling these groups to protect their "vital interest" (Trlin, 2017, p. 82).

\section{Conclusion}

The process of constitution-building can provide a forum for the negotiation of solutions to the divisive or contested issues that led to violence. It can also lead to the democratic education of the population, begin a process of healing and reconciliation through societal dialogue, and forge a new consensus vision of the future of the state (Samuels, 2006a, p. 667).

It is clear from the brief descriptions of consociationalism and federalism presented in this paper that the two models coincide in many respects and, most evidently, in that they both involve the sharing out of governmental power among a number of authorities in the country.

The empirical evidence shows that where conflicts have been successfully regulated in divided societies, one or more of the conflict-regulating practices characteristic of consociationalism and federalism have been employed (Boule, 1981, p. 253). It must be said, though, that from a mediator's point of view, the consociational model is a measure of last resort, adopted when communities can only live 'back to back' without integration (Samuels, 2006b, p. 9) and this was the case for Bosnia and Herzegovina.

Decentralization along ethnic lines can play an important role in reducing tensions by devolving decisionmaking authority and providing ethnic or sectarian groupings with a sense of local security. The potential negative side effects of such an approach, such as ethnic apartheid and the creation of new minorities, must be weighed against the potential for such a system to prevent a return to violent conflict. Even though the 
ethnically-based geographic divisions in Bosnia-Herzegovina have created new minorities within the entities and have encouraged ethnic flight in some areas, it is difficult to envision what option, other than outright partition, would have brought the conflict to an end (Samuels, 2006b, p.11).

The question underlying this paper, therefore, is to what extent federalism can help not only to end the violence in a conflict but also to address to root causes of this conflict and transform the relationships between the former enemies into more constructive and cooperative forms of interactions.

Federalism as a theory refers to the ideology of shared-rule and self-rule, to the connection of territorial autonomy and joined decision-making in central institutions at the same time. Its values focus on the celebration of diversity, mutual respect, reciprocity and a general will to cooperate and live together. Federalism can offer a solution to conflicts in which territorially concentrated minority nations demand recognition, autonomy and representation in central institutions (Keil, 2012, p. 207). Moreover, federalism has been, from the moment of the creation of the Dayton Peace Agreement until today, the only state structure which ensures the existence of Bosnia and Herzegovina as an independent state (Meskic y Pivic, 2011, p. 616).

Federalism can be a tool for transitional justice if the conflict is about the recognition of diversity, territorial autonomy and power-sharing in central institutions. This is why federalist theory and consociationalism, which focuses on power-sharing among different nations within one state, are highly interlinked, as both focus on the combination of territorial autonomy and elite power-sharing in central institutions. While federalism focuses more on a territorial solution to the conflict between different identities, consociationalism highlights the important of elite cooperation, veto rights and proportional representation.

Having said this, rather than favoring one over the other, societies in which different groups have been in conflict with each other over territory, autonomy, power in local and central institutions and over economic resources will require a complex institutional architecture to transform violence into new peaceful patterns of interaction. Therefore, power-sharing approaches from all sides, as well as different forms of territorial and nonterritorial autonomy need to be explored and applied to each case individually depending on the circumstances (Keil, 2012).

Because of this, Bosnia and Herzegovina can be seen as a major example of the combination of a federal political system with consociational power-sharing institutions that allow different communities to coexist in a peaceful and stable state.

\section{Bibliography}

Basta, K. (2016). Imagined institutions: the symbolic power of formal rules in Bosnia and Herzegovina. Slavic Review. Vol. 75, № 4, 944-969.

Belloni, R. (2007). State Building and International Intervention in Bosnia. Routledge.

Bieber, F. (2006). Post-War Bosnia. Ethnicity, Inequality and Public Sector Governance. Palgrave Macmillan.

Boule, L. (1981). Federation and Consociation - Conceptual Links and Current Constitutional Models. Tydskrif vir Hedendaagse Romeins-Hollandse Reg (Journal for Contemporary Roman-Dutch Law), 44(3), 236-254.

Brandt, M., Cottrell, J., Ghai, Y. and Regan, A. (2011). Constitution-making and Reform: Options for the Process, Interpeace, available at https://www.interpeace.org/resource/constitution-makingand-reform-options-for-the-process-2/

Burg, S. and Shoup, P. (2000). The war in Bosnia-Herzegovina. Ethnic conflict and international intervention. M.E. Sharp. 
Choudhry, S. (2014). Classical and Post-Conflict Federalism: Implications for Asia. In Guinsburg. T. and Dixon, R., Comparative Constitutional Law in Asia. (pp. 163-196). Edward Elgar Publishing.

Constitution of Bosnia and Herzegovina (as Amended in 2009), available at: https://www.refworld.org/do$\underline{\mathrm{cid} / 5 \mathrm{~b} 2 \mathrm{ba} 8 \mathrm{ab} 7 . \mathrm{html}}$

Elster, J. (1995). Forces and Mechanisms in the Constitution-Making Process, Duke Law Journal, 45(2), 364396.

Horowitz, D. (1985). Ethnic Groups in Conflict. University of California Press.

Kapidžić, D. (2020). Subnational competitive authoritarianism and power-sharing in Bosnia and Herzegovina. Southeast European and Black Sea Studies. Vol. 20, Nº1, 81-101.

Keil, S. (2012), Federalism as a Tool of Conflict-Resolution: The Case of Bosnia and Herzegovina. L'Europe en Formation, 361(1), 205-218. https://doi.org/10.3917/eufor.362.0205.

Kettley, C. (2001). Power-Sharing and Ethnic Conflict: The Consociational-Integrative Dichotomy and Beyond. European Yearbook of Minority Issues, 1, 247-268.

Kymlicka, W. (2009), Transitional Justice, Federalism and the Accommodation of Minority Nationalism. International Center for Transitional Justice.

Marko, J. (2005), Post-conflict Reconstruction through State- and Nation-building: The Case of Bosnia and Herzegovina. European Diversity and Autonomy Papers - EDAP 4/2005, 10, at www.eurac.edu/edap.

Meskic, Z.; Pivic, N. (2011). Federalism in Bosnia and Herzegovina. Vienna Journal on International Constitutional Law, 5(4), 597-617.

Murray, C. (2018). Constitutions: Frameworks for Pluralism, Global Centre for Pluralism. Available at: https://www.pluralism.ca/constitutions-frameworks-for-pluralism/

Lijphart, A. (1977). Democracy in Plural Societies: A Comparative Exploration. Yale University Press.

Loizides, N., Kovras, I., \& Ireton, K. (2011). Introduction: Federalism, reconciliation, and power-sharing in post-conflict societies. Federal Governance, 8(2), 1-14. https://nbn-resolving.org/urn:nbn:de:0168-ssoar-341891

Samuels, K. (2006). Post-Conflict Peace-Building and Constitution-Making, Chicago Journal of International Law, 6(2), 663-682.

Samuels, K. (2006). State-building and Constitutional Design after Conflict, IPA Report.

Sebastián-Aparicio, S. (2014). Post-War Statebuilding and Constitutional Reform. Palgrave Macmillan

Trlin, D. (2017). Limitations of the Democratic Capacity of the Constitutional System of Bosnia and Herzegovina. Beijing Law Review, 8(1), 79-99.

Williams, P., Sommadossi, T. and Mujais, A. (2017). A Legal Perspective on Yemen's Attempted Transition from a Unitary to a Federal System of Government. Utrecht Journal of International and European Law. 33(84), 4-22. https://doi.org/10.5334/ujiel.366. 